\title{
What does successful regulation look like?
}

\author{
Theodora Bloom deputy editor, The BMJ
}

Good regulation starts with a genuine need. Steele and colleagues (doi:10.1136/bmj.h1485) identify just such a need in describing the unregulated online market in human breast milk. Surveys reveal a burgeoning informal market, largely among mothers who aren't eligible for milk from established milk banks. But the message that "breast is best" drowns out concerns about safety. Inadequate screening and handling of samples risks transmission of infectious disease and bacterial contamination. Health professionals are urged to support alternatives to breast feeding where needed, but Steele and colleagues argue that legal regulation is also required.

It's widely understood that new antibiotics are needed to combat increasing resistance. But Peter Doshi argues (doi:10.1136/bmj. h1453) that, in the United States, legislation to speed new antibiotics to market may in fact be failing patients. Three of the five new antibiotics approved in 2014-15 have been judged to be as good as existing treatments for acute bacterial skin infections; but none has been found to be more effective, to meet an unmet medical need, or to tackle antimicrobial resistance. So, the legislative and regulatory push to facilitate the introduction of new therapies may have been

counterproductive. Lessons learnt painfully in the 20th century about the need for drug regulation risk being ignored by a new wave of legislators in the 21st. As Gonsalves and Zuckerman note in their commentary (doi:10.1136/bmj.h1500), AIDS activists of the 1980s and 1990s quickly learnt that speedier approval and wider access had downsides as well as upsides.

Successful regulation is not always underpinned by legislation. In the United Kingdom a group of alcohol producers, retailers, and trade organisations pledged in 2012 to remove a billion units of alcohol from the market by the end of 2015. An interim report on this voluntary agreement has announced success. But Holmes and colleagues (doi:10.1136/bmj.h1301) question whether the apparent reduction in alcohol units sold can be shown to have any relation to the pledge. They argue that a significant proportion of the apparent reduction was in fact due to a change in 2011 to the way customs and excise officials recorded data. It is also unclear whether the introduction of more lower strength products has driven particular consumers to switch from higher strength products or simply to add lower strength drinks to their diet. Clearly we need robust ways to assess the effect of any regulation, whether voluntary or statutory.

Perhaps the most that can be said of good regulation is that we know it when we see it. A prime example is outlined in the obituary of M Mujibur Rahaman (doi:10.1136/bmj.h455). His work at Bangladesh's Cholera Research Laboratory and later the International Centre for Diarrhoeal Diseases, Bangladesh, included development of oral rehydration salts and a demonstration that their deployment in rural villages could reduce diarrhoeal mortality by $20 \%$. His work stretched from direct research to governmental and non-governmental initiatives and regulations. Despite working through a liberation war and cooperating with a US government not universally welcomed in the newly independent Bangladesh, he helped develop preventive services, including wells, latrines, and education programmes, that collectively transformed life expectancy and infant mortality rates in rural Bangladesh. Success indeed.

Cite this as: BMJ 2015;350:h1641

๑ BMJ Publishing Group Ltd 2015 